\section{Nitrogen and Water Rates for Subsurface Trickle-irrigated Romaine Lettuce}

\author{
Thomas L. Thompson and Thomas A. Doerge \\ Department of Soil, Water, and Environmental Science, University of Arizona, \\ 429 Shantz Building \#38, Tucson, AZ 85721
}

Additional index words. Lactuca sativa, soil water tension

\begin{abstract}
Two field experiments were conducted with subsurface trickle-irrigated romaine lettuce (Lactuca sativa L. cv. Parris Island Cos) during the 1990-92 winter growing seasons in southern Arizona. The objectives were to determine 1) yield and quality response to varying combinations of soil water tension (SWT) and $\mathrm{N}$ fertilizer, 2) seasonal patterns of $\mathrm{N}$ uptake, and 3) unutilized fertilizer N. During 1990-91, $N$ rates were 35, 120, and 205 $\mathrm{kg} \cdot \mathrm{ha}^{-1}$. During 1991-92, the experiment was factorial with $\mathrm{N}$ levels from 50 to $300 \mathrm{~kg} \cdot \mathrm{ha}^{-1}$ and target $S W T$ levels of 7.0 and $4.0 \mathrm{kPa}$. Unutilized fertilizer $N$ was the difference between fertilized and nonfertilized plots in total $\mathrm{N}$ inputs not harvested in the crop. When excessive irrigation was not applied (SWT between 6.5 and $7.4 \mathrm{kPa}$ ), $95 \%$ of the maximum crop yield and yield quality (head length and fresh mass) response occurred at $N$ rates of 156 to 193 $\mathrm{kg} \cdot \mathrm{ha}^{-1}$, with unutilized fertilizer $N<60 \mathrm{~kg} \cdot \mathrm{ha}^{-1}$. Excessive irrigation $(4.6 \mathrm{kPa})$ resulted in lower yields and yield quality and higher unutilized fertilizer $\mathbf{N}$. Romaine accumulated $>74 \%$ of its total $\mathrm{N}$ uptake in the 38 days before harvest. Unutilized fertilizer $\mathrm{N}$ increased sharply when adequate $N$ and water rates were exceeded. These results suggest that a target SWT of no wetter than $6.5 \mathrm{kPa}$ is appropriate for subsurface trickle-irrigated romaine lettuce.
\end{abstract}

Crop production in arid regions is particularly sensitive to deficiencies of soil moisture and plant nutrients, especially N. In arid regions, high inputs of water and $\mathrm{N}$ fertilizers are commonly used for lettuce production. Rapid nitrification rates are typical under the thermic and hyperthermic conditions of the arid southwestern United States. Together, these conditions can contribute to increased production costs and the risk of groundwater nitrate pollution due to inefficient utilization of water and $\mathrm{N}$. However, management practices that increase water and $\mathrm{N}$ use efficiency must be economically feasible.

Growers generally apply 224 to $370 \mathrm{~kg} \mathrm{~N} /$ ha to lettuce grown in Arizona [Stivers et al., 1993; U.S. Dept. of Agriculture (USDA), 1991]. Recommended amounts are generally somewhat lower(Doerge et al., 1991). Total N absorption by lettuce is generally <136 $\mathrm{kg} \cdot \mathrm{ha}^{-1}$ (Stivers et al., 1993). Lettuce is a slowgrowing crop that often accumulates most of its biomass and $\mathrm{N}$ just before harvest. Zink and Yamaguchi (1962) found that head lettuce grown in the Salinas Valley of California attained $70 \%$ of its fresh weight and $\mathrm{N}$ accumulation in the 3 weeks before harvest. Gardner and Pew (1979) reported that a winter head lettuce crop grown in Arizona attained $80 \%$ of

Received for publication 9 Sept. 1994. Accepted for publication 27 Mar. 1995. This research was funded in part by a grant from the Tennessee Valley Authority and the Arizona Dept. of Environmental Quality. The cost of publishing this paper was defrayed in part by the payment of page charges. Under postal regulations, this paper therefore must be hereby marked advertisement solely to indicate this fact. its total $\mathrm{N}$ uptake during the 4 weeks before harvest. Large $\mathrm{N}$ applications, low $\mathrm{N}$ recovery, and large amounts of residual $\mathrm{N}$ may create significant potential for leaching losses of $\mathrm{NO}_{3}^{-}$from lettuce fields. For example, Adriano et al. (1972) estimated that $65 \%$ of $\mathrm{N}$ applied to lettuce in southern California was leached below the root zone.

Several methods exist for scheduling trickle irrigation, including evapotranspiration (Clough et al., 1990; Hartz, 1993; McNiesh et al., 1985), allowable soil water depletion (Bogle et al., 1989), and target soil water tensions (SWT). The advantages of using target SWTs were discussed by Pier and Doerge (1995a). Relatively few studies have been reported in which true "optimum" SWT values have been determined for trickle-irrigated crops from experiments with several levels of SWT. Phene and Beale (1976) reported that sweet corn (Zea mays L.) yields in a sandy loam soil were optimized when tension was maintained at 20 $\mathrm{kPa}$ at 0.15-m depth. Pier and Doerge (1995a) reported an optimum SWT of $7 \mathrm{kPa}$ for trickleirrigated watermelon [Citrullus lanatus (Thunb.) Matsu and Nakai] grown under hyperthermic conditions in a sandy loam soil. Feigin et al. (1982a) found that subsurface trickle-irrigated celery [Apium graveolens L. var dulce (Mill.) Pers.] produced the highest yield when SWT at a $0.2-\mathrm{m}$ depth was maintained at $7 \mathrm{kPa}$ in a sandy loam soil. According to Sammis (1980), trickle-irrigated head lettuce yields were maximized by maintaining SWT at $<20 \mathrm{kPa}$ in a clay loam soil, but an optimum SWT has not yet been reported for trickle-irrigated romaine.

All research conducted on trickle-irrigated lettuce has used heading cultivars. However, production of romaine lettuce has recently been increasing in Arizona (Sherman and Erwin, 1993). The objectives of this study were to determine 1) the response of romaine lettuce to varying combinations of SWT and N fertilizer, 2) seasonal patterns of $\mathrm{N}$ uptake, and 3 ) unutilized fertilizer $\mathrm{N}$ as affected by $\mathrm{N}$ and water rates.

\section{Materials and Methods}

Two field experiments using subsurface trickle irrigation were conducted at the Univ. of Arizona Maricopa Agricultural Center in southern Arizona during Winter 1990-92 growing seasons. Romaine ('Parris Island Cos') lettuce was planted during both seasons. The field used in both years is mapped as a Casa Grande sandy loam [fine-loamy, mixed, hyperthermic, typic Natriargid (reclaimed)]. The experimental area was cropped with nonfertilized, flood-irrigated sudangrass (Sorghum sudanenses L.) for 5 months before romaine was planted each season to reduce concentrations of available $\mathrm{N}$ in the root zone and reduce field variability. The aboveground biomass of the sudangrass was harvested and removed from the experimental area at least three times during the respective 5-month periods. Residual soil inorganic $\mathrm{N}\left(\mathrm{NH}_{4}^{+}+\mathrm{NO}_{3}^{-}\right)$was $<4$ $\mathrm{mg} \cdot \mathrm{kg}^{-1}$ following the final sudangrass harvest in each year.

Trickle tubing (Twin-wall IV, 0.36-mm wall thickness, $0.23-\mathrm{m}$ emitter spacing delivering $1 \times 10^{-3}$ liters $\cdot \mathrm{s}^{-1} \cdot \mathrm{m}^{-1}$ at $70 \mathrm{kPa}$; Chapin Watermatics, Watertown, N.Y.) was buried $0.15 \mathrm{~m}$ deep directly under the midline of north-south-oriented soil beds placed $1.02 \mathrm{~m}$ apart. Two seedlines were planted per bed $0.32 \mathrm{~m}$ apart and equidistant from the midline of the bed. Plants were thinned at the two- to three-leaf stage to final plant populations of 80,000 plants/ha. Uniform irrigation through the trickle tubing was continued on all plots until the stand was established (one- to twoleaf stage). Daily irrigations were then initiated by an automatic controller connected to electronic valves. Volumes of water applied by irrigation were monitored by duplicate inline propeller-type flow meters. The irrigation water used during each year had an electrical conductivity of $1.0 \mathrm{dS} \cdot \mathrm{m}^{-1}$ and an average $\mathrm{NO}_{3}-\mathrm{N}$ concentration of $2.0 \mathrm{mg} \cdot \mathrm{liter}^{-1}$.

Tensiometers were installed in selected, adequately fertilized plots within each water application treatment shortly after germination. Tensiometers were inserted vertically adjacent to the trickle tubing midway between two plants with the cups positioned at a depth of $0.3 \mathrm{~m}$. SWTs were measured daily before irrigation by use of a Tensicorder (Soil Measurement Systems, Tucson, Ariz.), as described by Marthaler et al. (1983). Irrigation was applied daily to maintain target SWT values, except when rainfall or cool weather made irrigation unnecessary. No pesticides were used in either year and weed control was by hand.

All $\mathrm{N}$ fertilizer was supplied as a solution of urea ammonium-nitrate ( $320 \mathrm{~g} \mathrm{~N} / \mathrm{kg}$ ). Fertilizer was injected directly into the irrigation 
water using venturi-type chemigators (Performance Products, Coolidge, Ariz.). Aboveground portions of lettuce plants were harvested from sections within each plot when plants were at harvestable size. Heads were trimmed to U.S. No. 1 specifications for romaine (USDA, 1960) and individually measured for mass and length. Unmarketable heads were separated and included with the trim component. The head and trim components were dried in a forced-air oven at $65 \mathrm{C}$, ground, and analyzed for total $\mathrm{N}$ using the microKjeldahl method modified to recover $\mathrm{NO}_{3}{ }^{-}$ (Bremner and Mulvaney, 1982). During both seasons, whole-plant samples for biomass and $\mathrm{N}$ accumulation measurements were collected from $1 \mathrm{~m}^{2}$ of row at $\approx 2$-week intervals beginning at the three- to four-leaf stage of growth. The entire aboveground portions of the plants were collected. The final sample collection (harvest) was 12 Mar. for the 1990-91 season and 30 Mar. for the 1991-92 season.

During the 1990-91 growing season, a N rate $\left(35,120,205 \mathrm{~kg} \cdot \mathrm{ha}^{-1}\right)$ experiment with split applications was conducted (Table 1); the design was a randomized complete block. The purpose of this initial experiment was to develop estimates of $\mathrm{N}$ and water requirements and $\mathrm{N}$ accumulation patterns for this cultivar. Plots (four beds $12.2 \mathrm{~m}$ long) were seeded on 25 Oct. and thinned on 29 Nov. Sprinkler irrigation was used for 8 days following seeding to enhance uniform germination and stand establishment. A total of $267 \mathrm{~mm}$ of water was applied during this period. Beginning on 31 Oct., sprinklers were removed and trickle irrigation was used to provide an adequate but not excessive amount of water. Irrigation scheduling was guided by feedback from the tensiometers. Irrigation water was applied in amounts necessary to maintain SWT at or near $7.0 \mathrm{kPa}$. The volumetric water content at $7.0 \mathrm{kPa}$ tension was $0.32 \mathrm{~m}^{3} \cdot \mathrm{m}^{-3}$, which represents $70 \%$ of the saturated volumetric water content. The seasonal average SWT and irrigation water amounts applied after stand establishment are shown in Table 2.

A total of $123 \mathrm{~kg} \mathrm{P} / \mathrm{ha}$ from phosphoric acid was injected into irrigation water applied to all plots on $8 \mathrm{Nov}$. at the one true-leaf growth stage. The amount of $\mathrm{NO}_{3}-\mathrm{N}$ applied in the irrigation water was $7.3 \mathrm{~kg} \cdot \mathrm{ha}^{-1}$. A total of $73 \mathrm{~mm}$ of rainfall fell between planting and harvest. The seasonal (seeding to harvest) potential evapotranspiration was $425 \mathrm{~mm}$, as determined by a weather station located near the experimental plots and a modified Penman equation.

During the 1991-92 growing season, the field experiment consisted of a $2 \times 4$ factorial randomized complete-block design with four replications. Cumulative $\mathrm{N}$ rates ranging from 50 to $300 \mathrm{~kg} \cdot \mathrm{ha}^{-1}$ were applied in five split applications (Table 1). These rates were intended to supply $\mathrm{N}$ over the range from deficient to excessive. Target SWTs were 7.0 and $4.0 \mathrm{kPa}$. Plots consisted of three 12.2-m-long beds, and the center bed was used for all harvest measurements. Seeds were planted on 14 Nov. and thinned on 17 Dec. A total of 843 $\mathrm{mm}$ of irrigation water was applied through the trickle tubing during the stand establishment period (14-27 Nov.). The higher amount of water needed for stand establishment during 1991-92 was due to 1) use of trickle tubing rather than sprinklers and 2) deeper than normal placement of the trickle tubing. During stand establishment, the objective was to maintain the soil wet. Irrigation treatments were initiated on $17 \mathrm{Dec}$., and daily irrigations were scheduled based on tensiometer feedback, as discussed above. An application of $123 \mathrm{~kg} \mathrm{P} /$ ha from triple superphosphate was applied uniformly to the field and incorporated before planting. The amount of $\mathrm{NO}_{3}-\mathrm{N}$ applied in the irrigation water was 4.5 and $14.8 \mathrm{~kg} \cdot \mathrm{ha}^{-1}$ for the two irrigation treatments. Rainfall received between planting and harvest was $179 \mathrm{~mm}$. The seasonal potential evapotranspiration between planting and harvest was $324 \mathrm{~mm}$.

Seasonal crop N uptake patterns were derived from the whole-plant sample data obtained during both seasons. Nitrogen uptake by the test crops was calculated as the product of the crop biomass (dry weight) and the $\mathrm{N}$ concentrations in plant material for each of the whole-plant sampling dates throughout the season. Smoothed cumulative $N$ uptake curves were constructed using compound cubic polynomials (Burden et al., 1981). The interpolant polynomials were then differentiated and plotted to define seasonal trends in daily $\mathrm{N}$ uptake (flux) (Crawford et al., 1982; Karlen et al., 1988). Regression models were fitted to data for yield characteristics, $\mathrm{N}$ uptake, and unutilized fertilizer $\mathrm{N}$ (defined below) (SAS Institute, 1985). Quadratic response models were used to identify maximum predicted response for these variables. The quadratic models were also used to identify levels of applied $\mathrm{N}$ corresponding to $95 \%$ of the maximum predicted response within the range of the treatments. We assumed that a response $<95 \%$ of the maximum would be unacceptable to growers.

Unutilized fertilizer $\mathrm{N}\left(\mathrm{UnN}_{\mathrm{i}}\right)$ was calculated by:

$\mathrm{UnN}_{\mathrm{i}}=\mathrm{FN}_{\mathrm{i}}+\left(\mathrm{WN}_{\mathrm{i}}-\mathrm{WN}_{\mathrm{o}}\right)-\left(\mathrm{PN}_{\mathrm{i}}-\mathrm{PN}_{\mathrm{o}}\right)$ [Eq. 1]

where $\mathrm{FN}_{\mathrm{i}}=$ fertilizer $\mathrm{N}$ applied to plot $\mathrm{i} ; \mathrm{WN}_{\mathrm{i}}$ $=\mathrm{N}$ applied in irrigation water to plot $\mathrm{i} ; \mathrm{WN}_{\mathrm{o}}$ $=\mathrm{N}$ applied in irrigation water to control plot; $\mathrm{PN}_{\mathrm{i}}=$ total aboveground crop $\mathrm{N}$ uptake in plot $\mathrm{i}$; and $\mathrm{PN}_{\mathrm{o}}=$ total crop $\mathrm{N}$ uptake in control plot harvest areas receiving no $\mathrm{N}$ fertilizer. Biom-

Table 1. Schedule of $\mathrm{N}$ fertilizer applications for romaine lettuce for the 1990-92 seasons.

\begin{tabular}{|c|c|c|c|c|c|c|c|}
\hline \multirow[b]{2}{*}{ Season } & \multirow[b]{2}{*}{ Growth stage } & \multirow[b]{2}{*}{ DAP $^{z}$} & \multirow[b]{2}{*}{$\mathrm{DCD}^{\mathrm{y}}$} & \multicolumn{4}{|c|}{ Total $\mathrm{N}$ applied $\left(\mathrm{kg} \cdot \mathrm{ha}^{-1}\right)$} \\
\hline & & & & 35 & 120 & 205 & --- \\
\hline \multirow[t]{6}{*}{ 1990-91 } & 1-2 Leaf & 19 & 332 & 0 & 15 & 30 & $\overline{---}$ \\
\hline & 3-4 Leaf & 40 & 596 & 15 & 30 & 45 & --- \\
\hline & 5-8 Leaf & 54 & 721 & 20 & 40 & 60 & --- \\
\hline & 10-12 Leaf & 82 & 864 & 0 & 20 & 40 & --- \\
\hline & Preharvest & 105 & 1065 & 0 & 15 & 30 & --- \\
\hline & & & & $\underline{50}$ & $\underline{120}$ & $\underline{190}$ & $\underline{300}$ \\
\hline \multirow[t]{5}{*}{ 1991-92 } & 1-2 Leaf & 33 & 286 & $\overline{0}$ & 15 & 25 & 45 \\
\hline & 4-6 Leaf & 54 & 452 & 10 & 20 & 35 & 60 \\
\hline & 10-12 Leaf & 83 & 695 & 30 & 50 & 65 & 90 \\
\hline & Early head & 98 & 867 & 10 & 25 & 45 & 70 \\
\hline & Preharvest & 119 & 1125 & 0 & 10 & 20 & 35 \\
\hline
\end{tabular}

${ }^{\mathrm{z} D A P}=$ days after planting.

y Degree C days (DCD) refers to accumulated heat units from 30.0 to 7.2C (Snyder, 1985).

Table 2. Target soil water tension (SWT), actual mean SWT, and amounts of water applied to romaine lettuce during 1990-92.

\begin{tabular}{llccr}
\hline & Irrigation & \multicolumn{2}{c}{ SWT (kPa) } & Water \\
\cline { 2 - 4 } Season & treatment & Target & Avg $^{2}$ & applied $\left(\mathrm{mm}^{\mathrm{y}}\right)$ \\
\hline $1990-91$ & Optimum & 7.0 & 7.4 & 409 \\
$1991-92$ & Optimum & 7.0 & 6.5 & 223 \\
& Excessive & 4.0 & 4.6 & 739 \\
\hline
\end{tabular}

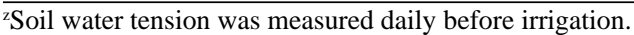

${ }^{\mathrm{y}}$ Water applied following the stand establishment period.

Table 3. Fresh weight and marketable yields, mean head length and mass, $N$ uptake, and unutilized fertilizer $\mathrm{N}$ for romaine lettuce in 1990-91 irrigated to $7.4 \mathrm{kPa}$ (average of soil water tension measured daily before irrigation).

\begin{tabular}{|c|c|c|c|c|c|c|}
\hline \multirow[b]{3}{*}{$\begin{array}{l}\mathrm{N} \text { applied } \\
\left(\mathrm{kg} \cdot \mathrm{ha}^{-1}\right)\end{array}$} & \multicolumn{2}{|c|}{ Romaine } & & & \multirow[b]{3}{*}{$\begin{array}{l}\text { N uptake } \\
\left(\mathrm{kg}^{\circ} \mathrm{ha}^{-1}\right)\end{array}$} & \multirow{3}{*}{$\begin{array}{c}\text { Unutilized } \\
\text { fertilizer N } \\
\left(\mathrm{kg} \cdot \mathrm{ha}^{-1}\right)\end{array}$} \\
\hline & \multirow{2}{*}{$\begin{array}{c}\text { Fresh } \\
\text { mass } \\
\left(\mathrm{Mg} \cdot \mathrm{ha}^{-1}\right)\end{array}$} & \multirow{2}{*}{ 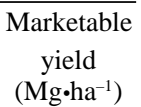 } & \multicolumn{2}{|c|}{ Head } & & \\
\hline & & & $\begin{array}{c}\text { Mass } \\
(\mathrm{g})\end{array}$ & $\begin{array}{c}\text { Length } \\
(\mathrm{cm})\end{array}$ & & \\
\hline 35 & 29.2 & 22.8 & 286 & 18.4 & 48 & 4 \\
\hline 120 & 65.5 & 52.6 & 657 & 26.1 & 104 & 49 \\
\hline 205 & 77.7 & 62.3 & 780 & 30.0 & 134 & 115 \\
\hline \multicolumn{7}{|l|}{ Significance } \\
\hline Replication & NS & NS & NS & NS & NS & NS \\
\hline Linear & $* * *$ & $* * *$ & $* * *$ & $* *$ & $* * *$ & $* * *$ \\
\hline Quadratic & $* *$ & $* *$ & $* *$ & NS & $*$ & $*$ \\
\hline
\end{tabular}

Ns, ${ }^{*},{ }^{* *},{ }^{* * *}$ Nonsignificant or significant at $P \leq 0.01,0.05$, or 0.01 , respectively. 
ass $\mathrm{N}$ was measured in control plots planted to several leafy vegetable crops in this field. Biomass $\mathrm{N}$ uptake for the entire season ranged from 6 to $12 \mathrm{~kg} \cdot \mathrm{ha}^{-1}$ for the various crops. To calculate unutilized fertilizer $\mathrm{N}$ for romaine for 1990-91 and 1991-92, biomass N uptake from a comparable lettuce cultivar was used $\left(12 \mathrm{~kg} \cdot \mathrm{ha}^{-1}\right)$. We assumed that this value will be relatively constant across years within this field following exhaustive cropping. We also assumed that the fate of indigenous $\mathrm{N}$ in control and fertilized plots was the same, and that only negligible amounts of $\mathrm{N}$ were contained in the root biomass (unpublished data, Bryant R. Gardner). The entire experimental area was subjected to exhaustive removal of soil $\mathrm{N}$ by multiple harvests of unfertilized sudangrass as well as leaching by several flood irrigation events. This procedure likely resulted in a low potential for soil $\mathrm{N}$ mineralization during the lettuce growing season. Therefore, any differences in $\mathrm{N}$ losses observed between fertilized and control plots are assumed to be the result of the $\mathrm{N}$ and water treatments, or their effects on lettuce growth and $\mathrm{N}$ recovery in plant biomass.

\section{Results and Discussion}

During 1990-91, the maximum predicted values for marketable weight, head mass, head length, and $\mathrm{N}$ uptake were all at the highest $\mathrm{N}$ level $\left(205 \mathrm{~kg} \cdot \mathrm{ha}^{-1}\right)$ (Table 3, Fig. 1). However, the values corresponding to $95 \%$ of the maximum predicted response occurred at $\mathrm{N}$ rates ranging from 156 to $177 \mathrm{~kg} \cdot \mathrm{ha}^{-1}$. Therefore, using yield and yield quality criteria, this range apparently was optimal for $\mathrm{N}$ fertilization under our conditions. Plant $\mathrm{N}$ uptake was not maximized within the range of the treatments (Fig. 1), indicating the occurrence of "luxury consumption" at supraoptimal to excessive $\mathrm{N}$ rates. The average of the daily measured tensions was $7.4 \mathrm{kPa}$, which corresponded very closely to the target SWT of $7.0 \mathrm{kPa}$.

During 1991-92, romaine yield responded to water and $\mathrm{N}$ (Table 4). Less irrigation water was applied during 1991-92 than during 199091 because of the higher rainfall amount received during 1991-92. With irrigation at 6.5 $\mathrm{kPa}$, predicted maxima for marketable yield, marketable head mass, and head length were at $\mathrm{N}$ rates of 274,274 , and $270 \mathrm{~kg} \cdot \mathrm{ha}^{-1}$, respectively (Fig. 2). However, the $\mathrm{N}$ rates corresponding to $95 \%$ of the maximum predicted response for these variables ranged from 179 to $193 \mathrm{~kg} \cdot \mathrm{ha}^{-1}$. Such $\mathrm{N}$ rates at $6.5 \mathrm{kPa}$ would have resulted in no more than $70 \mathrm{~kg} \cdot \mathrm{ha}^{-1}$ of unutilized fertilizer $\mathrm{N}$ (Fig. 2). At $4.6 \mathrm{kPa}$, however, no maxima for yield, yield quality measurements, or $\mathrm{N}$ uptake could be identified within the range of the treatments (Fig. 2). Therefore, the $\mathrm{N}$ rates needed to achieve $95 \%$ of maximum response were higher than at 6.5 $\mathrm{kPa}$, ranging from 270 to $274 \mathrm{~kg} \cdot \mathrm{ha}^{-1}$. Plant $\mathrm{N}$ uptake was also lower at $4.6 \mathrm{kPa}$. For any given $\mathrm{N}$ rate, marketable yield, head mass, and head length were lower at $4.6 \mathrm{kPa}$ compared to $6.5 \mathrm{kPa}$ (Table 3); therefore, more $\mathrm{N}$ was needed at $4.6 \mathrm{kPa}$ to achieve a similar yield. Lower yields and smaller heads with this irri-
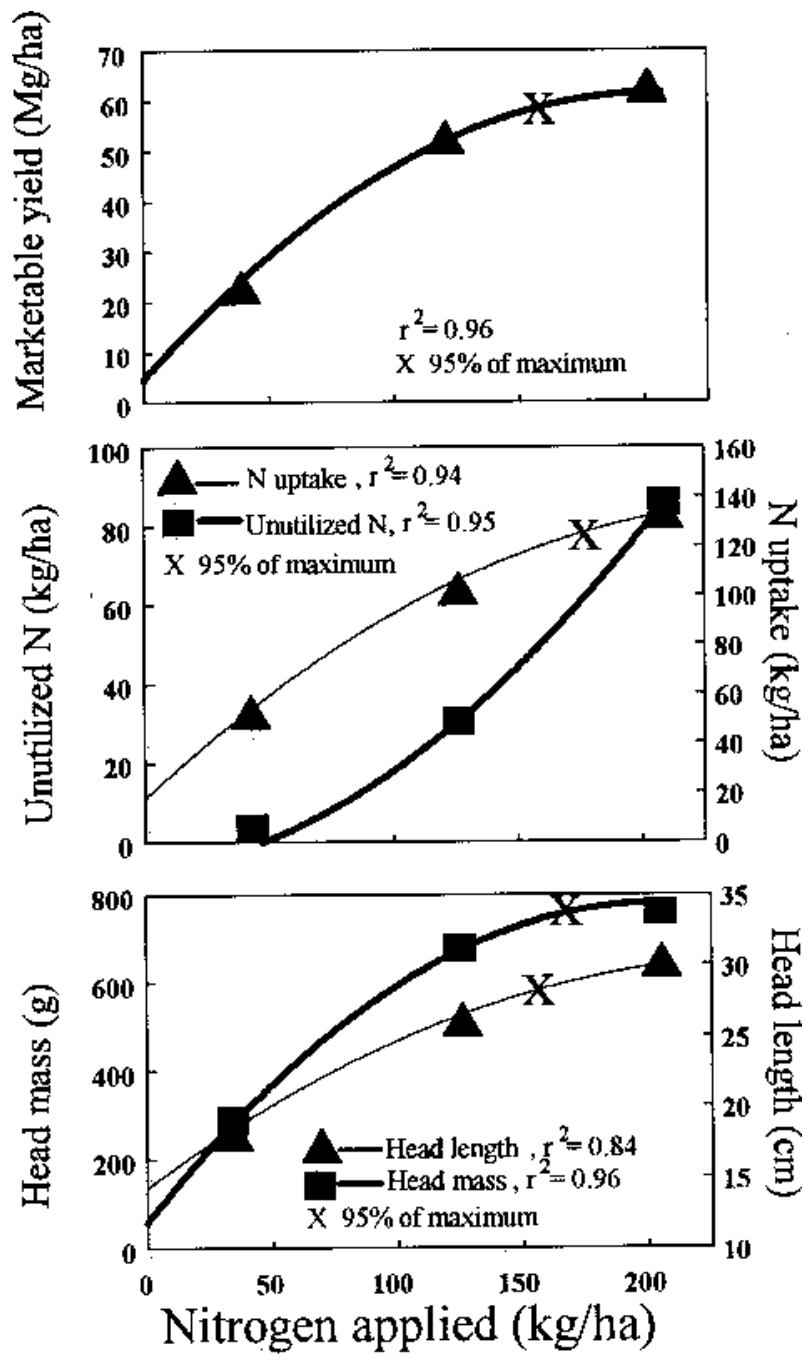

Fig. 1. Response of romaine lettuce marketable yield, head length, head mass, $\mathrm{N}$ uptake, and unutilized $\mathrm{N}$ to $\mathrm{N}$ fertilizer applications during 1990-91. Symbols represent treatment means; lines represent quadratic regression equations.

Table 4. Fresh weight and marketable yields, mean head length and mass, N uptake, and unutilized fertilizer $\mathrm{N}$ for romaine lettuce 1991-92.

\begin{tabular}{|c|c|c|c|c|c|c|c|}
\hline \multirow{3}{*}{$\begin{array}{l}\text { Irrigation } \\
\text { treatment } \\
\left(\mathrm{kPa}^{\mathrm{z}}\right)\end{array}$} & \multirow{3}{*}{$\begin{array}{c}\mathrm{N} \\
\text { applied } \\
\left(\mathrm{kg} \cdot \mathrm{ha}^{-1}\right)\end{array}$} & \multicolumn{2}{|c|}{ Romaine } & & & \multirow{3}{*}{$\begin{array}{c}\mathrm{N} \\
\text { uptake } \\
\left(\mathrm{kg} \cdot \mathrm{ha}^{-1}\right)\end{array}$} & \multirow{3}{*}{$\begin{array}{c}\text { Unutilized } \\
\text { fertilizer N } \\
\left(\mathrm{kg} \cdot \mathrm{ha}^{-1}\right)\end{array}$} \\
\hline & & \multirow{2}{*}{ 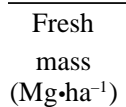 } & \multirow{2}{*}{ 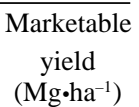 } & \multicolumn{2}{|c|}{ Head } & & \\
\hline & & & & $\begin{array}{c}\text { Mass } \\
(\mathrm{g})\end{array}$ & $\begin{array}{c}\text { Length } \\
(\mathrm{cm})\end{array}$ & & \\
\hline \multirow[t]{4}{*}{6.5} & 50 & 21.7 & 5.7 & 143 & 15.3 & 29 & 33 \\
\hline & 120 & 76.8 & 59.8 & 780 & 28.7 & 98 & 34 \\
\hline & 190 & 84.4 & 65.8 & 868 & 29.8 & 120 & 82 \\
\hline & 300 & 94.3 & 71.5 & 976 & 31.3 & 156 & 156 \\
\hline \multirow[t]{4}{*}{4.6} & 50 & 21.1 & 0 & 0 & 15.7 & 29 & 43 \\
\hline & 120 & 51.1 & 35.4 & 537 & 23.7 & 63 & 79 \\
\hline & 190 & 56.2 & 38.3 & 642 & 24.7 & 78 & 122 \\
\hline & 300 & 88.0 & 65.4 & 820 & 33.0 & 124 & 198 \\
\hline \multicolumn{8}{|l|}{ Significance } \\
\hline Replication & & NS & NS & NS & NS & NS & NS \\
\hline Water (SWT) & & $* * *$ & $* * *$ & $* * *$ & $*$ & $* * *$ & $* * *$ \\
\hline \multicolumn{8}{|l|}{ Nitrogen } \\
\hline Linear & & $* * *$ & $* * *$ & $* * *$ & $* * *$ & $* * *$ & $* * *$ \\
\hline Quadratic & & $* * *$ & $* * *$ & $* * *$ & $* * *$ & $* *$ & $* *$ \\
\hline Cubic & & $* *$ & $* * *$ & $* * *$ & $* *$ & NS & NS \\
\hline \multicolumn{8}{|l|}{ Interactions } \\
\hline $\mathrm{SWT} \times \mathrm{N}$ & & NS & NS & NS & NS & $*$ & $*$ \\
\hline $\mathrm{SWT} \times \mathrm{N} \times \mathrm{N}$ & & $* *$ & $* *$ & $* *$ & $* *$ & $*$ & $*$ \\
\hline \multicolumn{8}{|l|}{$\mathrm{SWT} \times \mathrm{N} \times$} \\
\hline $\mathrm{N} \times \mathrm{N}$ & & NS & NS & NS & NS & NS & NS \\
\hline
\end{tabular}

${ }^{\mathrm{z}}$ Average of soil water tension measured daily before irrigation.

Ns, *,**,**Nonsignificant or significant at $P \leq 0.10,0.05$, or 0.01 , respectively. 
gation treatment likely would be economically detrimental for a grower.

Both the linear and quadratic terms for $\mathrm{N}$ for all response variables were significant at $P$ $\leq 0.05$ (Table 4 ). The simple interaction terms were nonsignificant at $P \leq 0.10$; however, the quadratic interaction term $(\mathrm{N} \times \mathrm{N} \times \mathrm{SWT})$ was significant at $P \leq 0.05$ for some variables. Overall, response to $\mathrm{N}$ was much more pronounced than response to water. The interaction between SWT and N was more pronounced at low and high $\mathrm{N}$ rates (Fig. 2).

Patterns of $\mathrm{N}$ accumulation for romaine in the $6.5 \mathrm{kPa}$ irrigation treatment during 199192 (Fig. 3A) showed little N uptake before 75 days after planting (590 accumulated heat units, 30.0 to $7.2 \mathrm{C}$ ). Patterns of $\mathrm{N}$ accumulation during 1990-91 were similar (data not
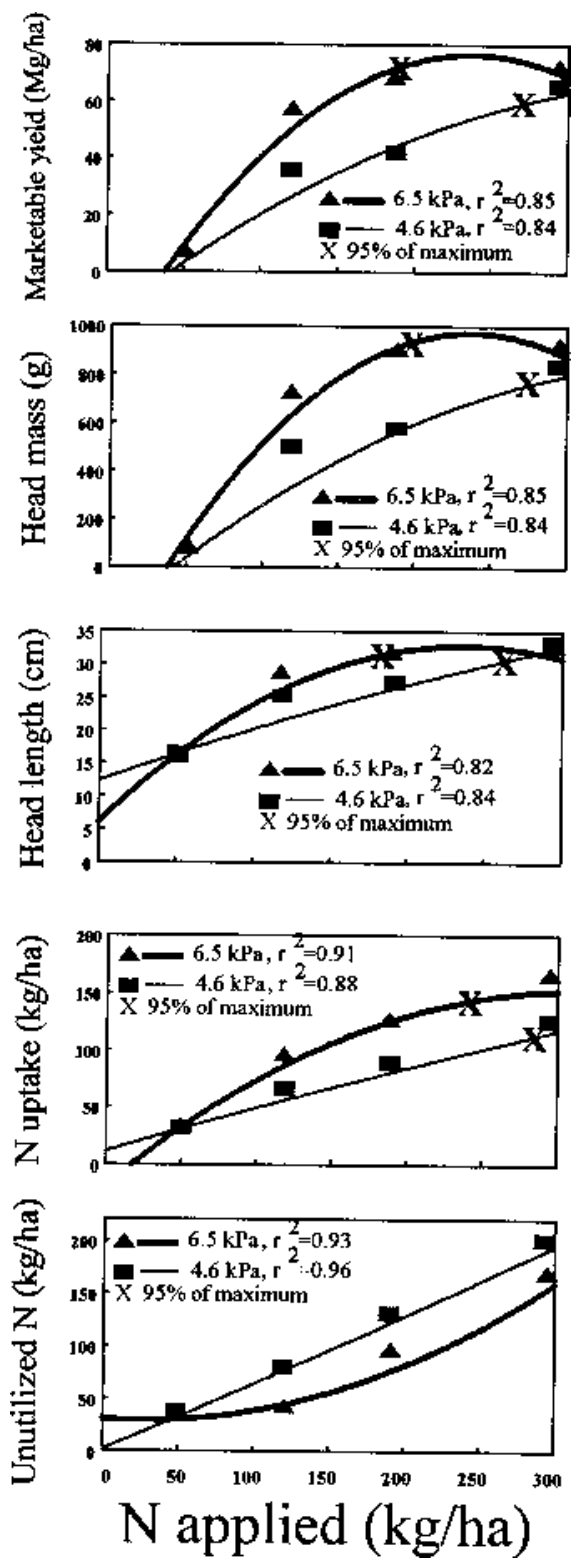

Fig. 2. Response of romaine lettuce marketable yield, head length, head mass, $\mathrm{N}$ uptake, and unutilized $\mathrm{N}$ to soil water tension and $\mathrm{N}$ fertilizer applications during 1991-92. Symbols represent treatment means; lines represent quadratic regression equations.
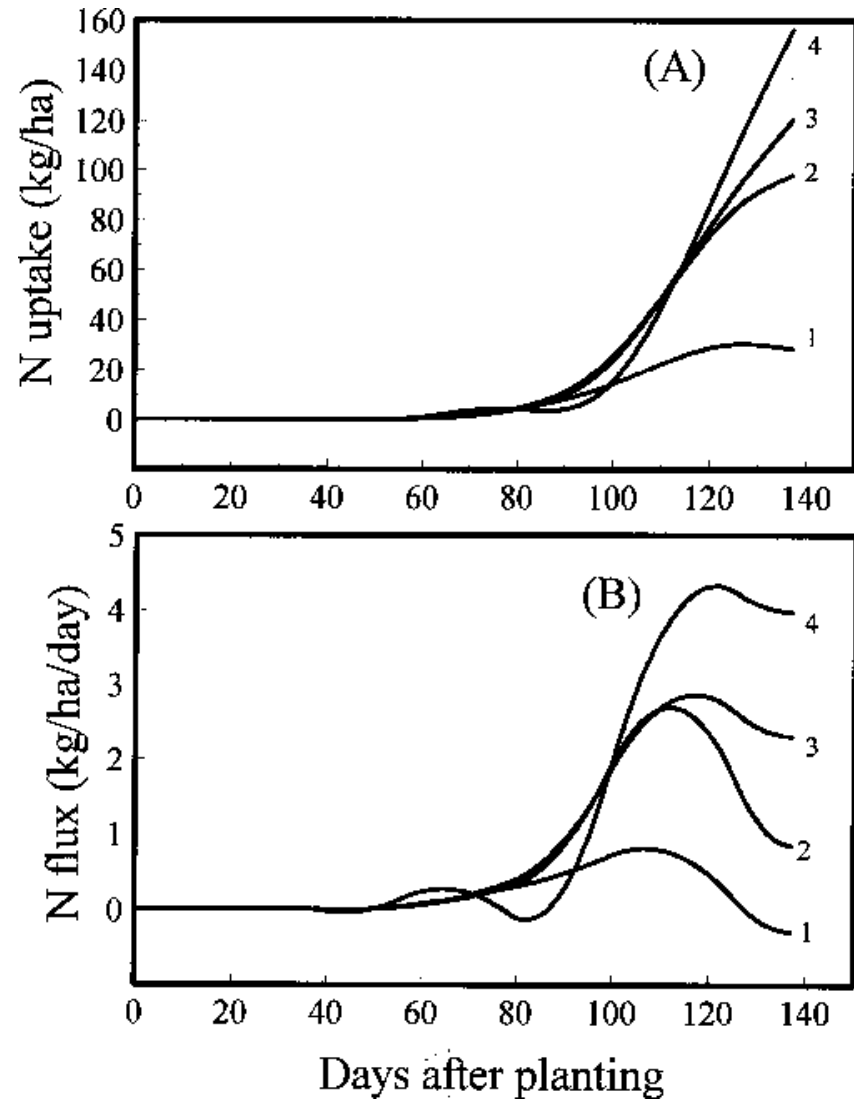

Fig. 3. Nitrogen accumulation for romaine lettuce during the 1991-92 season: (A) cumulative $\mathrm{N}$ accumulation, (B) daily $\mathrm{N}$ flux.

shown). Romaine took up an average of $74 \%$ of its total $\mathrm{N}$ accumulation in the 38 days before harvest, which is similar to results reported by Zink and Yamaguchi (1962) and Gardner and Pew (1979) for head lettuce. The point of maximum $\mathrm{N}$ flux in romaine (Fig. 3B) was similar in all $\mathrm{N}$ treatments. Maximum dry matter and $\mathrm{N}$ accumulation were somewhat greater for romaine grown during 1991-92 than during 1990-91 (Table 5), reflecting the higher yields that occurred during 1991-92 (Table 4). Maxima for dry matter and $\mathrm{N}$ flux were similar for the two seasons. In each season, maximum dry matter and $\mathrm{N}$ flux were measured $\approx 2$ weeks before harvest. These data illustrate the importance of timely $\mathrm{N}$ applications for romaine but also point out the dilemma facing lettuce producers. Nitrogen applications made before or early in the growing season, when plant $\mathrm{N}$ demand is low, are likely to be inefficiently used and may pose a threat for groundwater nitrate contamination. However, $\mathrm{N}$ deficiencies occurring early in the growing season also may severely reduce grower profits by lowering crop yield, quality, or earliness.

The maximum mean aboveground $\mathrm{N}$ uptake by romaine lettuce during the two seasons was $156 \mathrm{~kg} \cdot \mathrm{ha}^{-1}$ (Table 4), which is higher than has been reported for most lettuce cultivars (Stivers et al., 1993). Lorenz and Maynard (1988) estimated average $\mathrm{N}$ absorption by lettuce crops to be $106 \mathrm{~kg} \cdot \mathrm{ha}^{-1}$. One possible reason for the high $\mathrm{N}$ uptake reported here is that, in these experiments, romaine was har- vested near the end of the normal commercial harvesting window. During the two experiments, an average of $69 \%$ of all $\mathrm{N}$ taken up by the plants was contained in the marketable heads. The remaining 31\% was contained in wrapper leaves and unmarketable heads (designated as trim) (data not shown). This portion of the plant material is normally left in the field in commercial operations. The proportion of biomass $\mathrm{N}$ contained in unmarketable portions showed a general decrease as fertilization rates increased. This pattern reflects the increase in size of heads and the lower percentage of unmarketable heads in the high-N treatments. During 1991-92, there was a definite trend toward lower $\mathrm{N}$ uptake with excessive irrigation (Fig. 2), probably reflecting lower $\mathrm{N}$ availability in the crop root zone due to leaching, denitrification, or both. Feigin etal.(1982b) noted lower $\mathrm{N}$ uptake by trickle-irrigated celery when excessive irrigation was applied. Bar-Yosef and Sagiv (1982) observed a similar trend for trickle-irrigated tomato (Lycopersicon esculentum Mill.).

Unutilized fertilizer $\mathrm{N}$ accounts for $\mathrm{N}$ inputs from fertilizers, irrigation water, and soil $\mathrm{N}$ mineralization. Amounts of $\mathrm{N}$ applied in irrigation water ranged from 4.5 to 14.8 $\mathrm{kg} \cdot \mathrm{ha}^{-1}$, depending on the total amount of water applied. The amount of $\mathrm{N}$ taken up by plants within the control plots in excess of that supplied in the irrigation water was 5.5 $\mathrm{kg} \cdot \mathrm{ha}^{-1}$. Unutilized fertilizer $\mathrm{N}$ may remain in the soil as residual N, or may be lost from the system by leaching or gaseous losses. During 
Table 5. Maximum values for total $\mathrm{N}$ uptake, biomass accumulation, and flux of dry matter and biomass $\mathrm{N}$ for romaine lettuce, 1990-92.

\begin{tabular}{|c|c|c|c|c|c|}
\hline \multirow[b]{2}{*}{ Season } & \multicolumn{2}{|c|}{ Dry matter } & \multicolumn{2}{|c|}{ N uptake } & \multirow{2}{*}{$\begin{array}{c}\text { DCD at } \\
\text { maximum } \\
\text { flux }^{z}\end{array}$} \\
\hline & 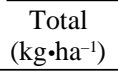 & 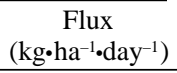 & $\begin{array}{c}\text { Total } \\
\left(\mathrm{kg} \cdot \mathrm{ha}^{-1}\right)\end{array}$ & $\begin{array}{c}\text { Flux } \\
\left(\mathrm{kg} \cdot \mathrm{ha}^{-1} \cdot \text { day }^{-1}\right)\end{array}$ & \\
\hline$\overline{1990-91}$ & 4102 & 122 & 132 & 3.8 & 1260 \\
\hline 1991-92 & 5340 & 143 & 156 & 4.1 & 1125 \\
\hline
\end{tabular}

${ }^{2}$ Degree C days (DCD) refers to accumulated heat units from 30.0 to 7.2C (Snyder, 1985).

1990-91, especially sharp increases in predicted unutilized fertilizer $\mathrm{N}$ occurred when applications were $\geq 120 \mathrm{~kg} \mathrm{~N} / \mathrm{ha}$ (Fig. 1). During 1991-92, the slope of the curve for unutilized fertilizer $\mathrm{N}$ was steepest when $\mathrm{N}$ rates exceeded the rate associated with $95 \%$ of maximum predicted response (Fig. 2). At $\mathrm{N}$ rates $\geq 50 \mathrm{~kg} \cdot \mathrm{ha}^{-1}$, predicted unutilized fertilizer $\mathrm{N}$ was higher at $4.6 \mathrm{kPa}$ than at $6.5 \mathrm{kPa}$. Much of the unutilized fertilizer $\mathrm{N}$ likely remained within the soil profile in the $6.5-\mathrm{kPa}$ irrigation treatment, but was lost by leaching or denitrification at $4.6 \mathrm{kPa}$ (Pier and Doerge, 1995b). Plants were apparently able to utilize $\mathrm{N}$ more efficiently when provided with adequate, rather than excessive, irrigation.

Two years of experimentation with trickleirrigated romaine lettuce were conducted in southern Arizona under very high-yielding conditions. When irrigation was not excessive (low SWT), predicted maxima for marketable yield, head weight, and head length occurred at 205 to $274 \mathrm{~kg} \mathrm{~N} / \mathrm{ha}$. However, $\mathrm{N}$ rates associated with $95 \%$ of maximum predicted response during the two years were 156 to 193 $\mathrm{kg} \cdot \mathrm{ha}^{-1}$ when irrigation was not excessive. An average SWT of $4.6 \mathrm{kPa}$ apparently represented excessive irrigation. The $\mathrm{N}$ rate needed to attain maximum yield, head weight, and head length was higher at 4.6 than at $6.5 \mathrm{kPa}$ during 1991-92. The $\mathrm{N}$ rate associated with $95 \%$ of maximum predicted yield was $\approx 270$ $\mathrm{kg} \cdot \mathrm{ha}^{-1}$ at $4.6 \mathrm{kPa}$. In each year, romaine accumulated $>74 \%$ of its total $\mathrm{N}$ uptake within the 38 days before harvest. Maximum $\mathrm{N}$ uptake in the romaine biomass was $156 \mathrm{~kg} \cdot \mathrm{ha}^{-1}$. Applications of excessive amounts of $\mathrm{N}$ or irrigation water resulted in increases in unutilized fertilizer $\mathrm{N}$, which includes fertilizer $\mathrm{N}$ not taken up in the plant biomass. Overall, the results indicate that the wet ( $4.6 \mathrm{kPa}$ SWT) irrigation treatment during 1991-92 resulted in lower crop yields and quality and created conditions conducive to $\mathrm{N}$ losses. These results suggest that a target SWT of no wetter than $6.5 \mathrm{kPa}$ is appropriate for subsurface trickle-irrigated romaine lettuce.

\section{Literature Cited}

Adriano, D.C., F.H. Takatori, P.F. Pratt, and O.A. Lorenz. 1972. Soil nitrogen balance in selected row-crop sites in southern California. J. Environ. Qual. 1:279-283.

Bar-Yosef, B. and B. Sagiv. 1982. Response of tomatoes to $\mathrm{N}$ and water applied via a trickle irrigation system. II. Water. Agron. J. 74:637639.

Bogle, C.R., T.K. Hartz, and C. Nunez. 1989. Comparison of subsurface trickle and furrow irrigation on plastic-mulched and bare soil for tomato production. J. Amer. Soc. Hort. Sci. 114:40-43.

Bremner, J.M. and C.S. Mulvaney. 1982. Nitrogentotal. In: A.L. Page et al. (ed.). Methods of soil analysis. part II. 2nd ed. Agronomy 9:595-624.

Burden, R.L., J.D. Faires, and A.C. Reynolds. 1981 Numerical analysis. Prindle, Weber, and Schmidt, Boston.

Clough, G.H., S.J. Locascio, and S.M. Olson. 1990. Yield of successively cropped polyethylenemulched vegetables as affected by irrigation method and fertilization management. J. Amer. Soc. Hort. Sci. 115:884-887.

Crawford, T.W., V.V. Rendig, and F.E. Broadbent. 1982. Sources, fluxes, and sinks of nitrogen during early reproductive growth of maize ( $\mathrm{Zea}$ mays L.). Plant Physiol. 70:1654-1660.

Doerge, T.A., R.L. Roth, and B.R. Gardner. 1991 Nitrogen fertilizer management in Arizona. The Univ. of Arizona, College of Agr., Rpt. 191025.

Feigin, A., J. Letey, and W.M. Jarrell. 1982a. Celery response to type, amount and method of $\mathrm{N}$ fertilizer application under drip irrigation. Agron. J. 74:971-977.

Feigin, A., J. Letey, and W.M. Jarrell. 1982b. Nitrogen utilization efficiency by drip irrigated celery receiving preplant or water applied $\mathrm{N}$ fertilizer. Agron. J. 74:978-983.

Gardner, B.R. and W.D. Pew. 1979. Comparison of various nitrogen sources for the fertilization of winter-grown head lettuce. J. Amer. Soc. Hort. Sci. 104:534-536.
Hartz, T.K. 1993. Drip irrigation scheduling for fresh-market tomato production. HortScience 28:35-37.

Karlen, D.L., R.L. Flannery, and E.J. Sadler. 1988. Aerial accumulation and partitioning of nutrients by corn. Agron. J. 80:232-242.

Lorenz, O.A. and D.N. Maynard. 1988. Knott's handbook for vegetable growers. Wiley Interscience, New York.

Marthaler, H.P., W. Vogelsanger, F. Richard, and P.J. Wierenga. 1983. A pressure transducer for field tensiometers. Soil Sci. Soc. Amer. J. 47:624-627.

McNiesh, C.M., N.C. Welch, and R.D. Nelson. 1985. Trickle irrigation requirements for strawberries in coastal California. J. Amer. Soc. Hort. Sci. 110:714-718.

Phene, C.J. and O.W. Beale. 1976. High-frequency irrigation for water and nutrient management in humid regions. Soil Sci. Soc. Amer. J. 40:430436.

Pier, J.W. and T.A. Doerge. 1995a. Nitrogen and water interactions in trickle irrigated watermelon. Soil Sci. Soc. Amer. J. 59:145-150.

Pier, J.W. and T.A. Doerge. 1995b. Concurrent evaluation of agronomic, economic, and environmental aspects of trickle irrigated watermelon production. J. Environ. Qual. 24:7986.

Sammis, T.W. 1980. Comparison of sprinkler, trickle subsurface and furrow irrigation methods for row crops. Agron. J. 72(5):701-704.

SAS Institute. 1988. SAS/STAT users guide, release 6.03 ed. SAS Inst., Cary, N.C.

Sherman, W. and B. Erwin. 1993. 1992 Arizona agricultural statistics. Bulletin S-28. Arizona Agr. Statistics Serv., Phoenix.

Snyder, R.L. 1985. Hand calculating degree days. J. Agr. Forest Meteorol. 35:353-358.

Stivers, L.J., L.E. Jackson, and G.S. Pettygrove. 1993. Use of nitrogen by lettuce, celery, broccoli, and cauliflower: A literature review. Calif. Dept. of Food \& Agr. Sacramento, Calif.

U.S. Department of Agriculture. 1960. United States standards for grades of romaine. AMS Publ. 25 FR 6236. U.S. Govt. Printing Office, Washington, D.C.

U.S. Department of Agriculture. 1991. Agricultural chemical usage 1990, vegetable summary. Natl Agr. Stat. Serv., Econ. Res. Serv., Washington, D.C

Wierenga, P.J. and M.H. Saddiq. 1985. Optimum soil water tension for trickle irrigated chile peppers. Drip/Trickle Irrigation in Action, Proc. Third Intl. Drip/Trickle Irrig. Conf. vol. I, ASAE Publ. 10-85. p. 193-197.

Zink, F.W. and M. Yamaguchi. 1962. Studies on the growth rate and nutrient absorption of head lettuce. Hilgardia 32:471-500. 